\title{
ADJUDICATION AND THE GOVERNING PROCESS: POLITICAL QUESTIONS AND LEGISLATIVE DISCRETION
}

\author{
Taisuke Kamata* \\ I \\ INTRODUCTION
}

This paper discusses decisions of the Japanese Supreme Court that recognize that some governmental questions lie entirely within the discretion of the Diet or the discretion of other political branches of government. Such questions are subject to the most lenient judicial scrutiny or are found to lie completely outside the scope of judicial review. In constitutional litigation these questions are referred to as either "matters of legislative discretion" or "political questions."'

The Court has recognized that the Diet has broad discretionary power to enact legislation concerning crime and punishment, family relations, elections, social welfare, the status of public employees, and economic regulations. First, I will introduce some recent cases in which the Court has applied the legislative discretion test, and then I will refer to some common features of these cases. Next I will consider the constitutional limitations of this test and comment on the appropriate relationship between the Diet and the Court.

\section{II}

\section{Matters of Legislative Discretion and Political Questions}

During the past four decades, the Supreme Court has held that some constitutional questions are matters of legislative discretion or are political questions. Consequently, the Court has refrained from interfering in matters relating to political decisions by government.

\footnotetext{
Copyright $(\mathcal{O} 1990$ by Law and Contemporary Problems

* Professor, Faculty of Law, Doshisha University.

1. The legislative discretion test and the political question doctrine are not referred to in the Constitution; they are creations of the Supreme Court. Comprehensive analyses of these issues appear in Kobayashi, The Doctrine of Political Questions, in 1 Constitutional Litigation 321 (N. Ashibe ed. 1987); Nonaka, The Theory of Legislative Discretion, in 2 Constrtutional Litication 93 (N. Ashibe ed. 1987); Tomatsu, The Theory of Legislative Discretion, in Modern States and the Principles of Constitutions 187 (Association for Studying Modern Constitutions ed. 1983).
} 


\section{A. A Case on Illegitimacy}

The first case concerns the status of illegitimate children. ${ }^{2}$ Under Japanese family law, a child born out of wedlock is treated as an illegitimate child and is forced into a disadvantaged position in society. Illegitimate children are allowed to use only their mother's family name and enjoy property rights differently from legitimate children. Japanese family law recognizes, however, that illegitimate children can be legitimated through voluntary acknowledgement by their father or through a court order. A child can be legitimated both ways while the father is still alive, but if the father is dead, the child can be legitimated only through a court order. The child's claim must be brought before the court within three years of the father's death.

This three-year rule was challenged in a Kyoto District Court case. In 1947 , the plaintiff was born to a young couple who had a traditional wedding ceremony in an old Shinto shrine in 1946 but who did not register their marriage at the appropriate local government office. As a result, the plaintiff was deemed illegitimate and was registered on his mother's record even though the family lived together as an ordinary family. One year after the plaintiff was born, his father died. In 1951, the plaintiff brought suit to be declared legitimate. However, on the first day of the trial, both parties were absent because the plaintiff's attorney was ill. Ordinarily, in such a case, the lawyer would ask the trial judge to set a new trial date. In this case, however, the lawyer failed to file such a motion, and, unfortunately, he died two months after the date of the first trial.

The plaintiff and his mother failed to receive notice of their lawyer's sudden death and the status of their pending case from their lawyer's family. The plaintiff believed that his case was proceeding in court. In fact, his case had already been dismissed by the court, in accordance with the Civil Procedure Act, which provides that if a plaintiff or his agent is absent from a trial and does not ask for a new trial within three months, the court may dismiss the case. The court may infer that the plaintiff withdrew his claim after three months' absence.

As soon as the plaintiff and his mother learned of their lawyer's death, they again brought their case to court. However, the Kyoto District Court dismissed the case, relying on the "within three years of the death of the father" clause. The decision was sustained by the Osaka High Court. The plaintiff appealed to the Supreme Court, claiming that the time limit violated Articles 13 and 14 of the Japanese Constitution. The Supreme Court held that the time limit was constitutional and that requirements for raising claims for legitimization lay entirely within the legislature's discretion. The threeyear time limit provided certainty in the law of family relationships and, as such, was within the legislature's responsibility. Since the Court resolved this case in a short opinion, it has not attracted the attention of constitutional

2. Ono v. Japan, 9 Minshū 1122 (Sup. Ct., G.B., July 20, 1955). 
scholars. Nevertheless, the case addressed a very important aspect of legislative discretion.

\section{B. A Patricide Case}

Article 200 and section 2 of Article 205 of the Penal Code impose heavier penalties for patricide and matricide, including accidental murders of fathers or mothers, than for ordinary homicide and accidental death. ${ }^{3}$ In 1950 , the Fukuoka District Court held that section 2 of Article 205 was an unconstitutional violation of Article 14 of the Constitution. ${ }^{4}$ The Supreme Court reversed the lower court's decision, stating that:

The [district court] decision holds that although family relations can be considered in weighing penalties, this is no reasonable basis to provide for inequality [of punishment] therein by means of law. However, we find that if it is feudalistic and anti-democratic, as the original judgment states, to emphasize the special moral relationship of children and parents, and if, consequently, a law based on this emphasis is unconstitutional, then it is also unconstitutional to take these circumstances into consideration, in weighing penalties when rendering judgment. Or, stated conversely, if one can take these circumstances into consideration constitutionally, then it is also possible constitutionally to go a step further and to objectify them in the form of law. ${ }^{5}$

In this case, the Supreme Court upheld the constitutionality of broad legislative discretionary power to set crimes and punishments. The Supreme Court held that the reasoning quoted above was a legitimate and reasonable basis for the constitutionality of Article 200 and section 2 of Article 205, until the heavier criminal penalties prescribed in Article 200 were finally found unconstitutional in a 1973 patricide case. ${ }^{6}$

\section{Salaried Workers' Income Tax Case}

The income tax law provides for a deduction of costs in separating taxable profits from gross profits in assessing income taxes. However, the law treats salaried workers and nonsalaried workers differently in allowing the deduction of costs. In the case of salaried workers, legally fixed costs may be deducted, but nonsalaried workers may subtract only real costs. In extended litigation, a salaried worker attacked this system as leading to unconstitutional

3. Article 200 provides that a "person, who kills his lineal ascendant or a lineal ascendant of his spouse, shall be punished with death or penal servitude for life." Article 205 provides that

A person, who inflicts an injury upon the person of another and thereby causes the latter's death, shall be punished with penal servitude for a limited period of not less than two years. When the crime is committed against a lineal ascendant of the offender or of the spouse thereof, the offender shall be punished with penal servitude for life or not less than three years.

Keihō (Penal Code), arts. 200, 205.

4. 4 Keishū 2037 (The Fukuoka Patricide Case) (Sup. Ct., G.B., Oct. 11, 1950) (reversing decision of the Fukuoka District Court of January 9, 1950); J. Makı, Court and Constitution IN JAPAN 129 (1964).

5. J. Maki, supra note 4, at 129 .

6. Aizawa v. Japan, 27 Keishū 265 (Sup. Ct., G.B., Apr. 4, 1973) (aff'g l Keisai Geppō 544 (Utsunomiya Dist. Ct., May 29, 1969) and rev'g 619 Hanrei Jihò 93 (Tokyo H. Ct., May 12, 1970)); Beer, Japan's Constitutional System and lts Judicial Interpretation, 17 LAW IN JAPAN 7. 36 (1984). 
inequalities. $^{7}$ The Supreme Court upheld the constitutionality of the system on the ground that the authority to set tax policy was delegated to the legislature. Thus, courts must defer to the legislative judgment on taxes unless it is clearly unreasonable.

\section{Economic Regulation Cases}

The Diet possesses especially broad discretionary power to regulate economic activities under the public welfare clauses of Articles 22 and 29 of the Constitution. In cases where economic regulations have been challenged as unconstitutional, courts have repeatedly deferred to legislative judgment. Thus, economic regulations have been subjected to the most lenient judicial review, and almost all restrictions have been held constitutional.

Licensing is a popular form of economic regulation. Licenses issued by local governments are required for businesses such as pharmacies, public bathhouses, and markets. The government agency checks various conditions specified by statute before issuing a license. As a condition for acquiring a license, the licensee is required to establish a business at a certain distance (for instance, 250 meters in the case of a public bathhouse) from similar businesses operating in the neighborhood.

In 1955, the Supreme Court held such restrictions constitutional as applied to public bathhouses. ${ }^{8}$ The Court justified distance regulations as a way to maintain high sanitary standards in public baths:

Public baths are welfare facilities of a highly public nature, indispensable to the daily life of the majority of the people. Moreover, in the event that their establishment be left to the will of the entrepreneur himself and necessary measures are not taken to preserve their proper distribution or to prevent maldistribution and excessive numbers, it is to be feared not only that such maldistribution may cause inconvenience to many people who wish easy access to public baths daily but also that excessive numbers thereof may lead to futile competition and have an unfavorable economic effect on the enterprises, thereby giving rise to undesirable consequences such as a deterioration in the sanitary facilities of the bathhouses. ${ }^{9}$

\section{E. Cases on Election Law}

The Constitution provides for terms of office for members of the Diet, universal adult suffrage, and secrecy of the ballot. ${ }^{10}$ Other matters pertaining to elections, including the size of each legislative house, qualifications of Diet members, boundaries of electoral districts, and voting procedures, are to be fixed by law. ${ }^{11}$

The Diet is regarded as possessing broad discretionary power in making election rules. The Diet has established rules concerning qualifications of voters and candidates, election district boundaries and apportionment of Diet

7. Oshima v. Hamaguchi, 39 Minshū 247 (Sup. Ct., G.B., Mar. 27, 1985).

8. Shimizu v. Japan (Fukuoka bathhouse decision), 9 Keishū 89 (Sup. Ct., G.B., Jan. 1, 1955); J. MAKI, supra note 4 , at 295.

9. J. Maki, supra note 4, at 295-96.

10. 1947 Const. arts. 15, 46, 47.

11. Id. arts. $43,44$. 
members among them, election campaigns, voting procedures, and petitions against the validity of elections. Restrictions on election campaigns and apportionments have repeatedly resulted in constitutional litigation concerning whether these legislative decisions have violated freedom of expression or equal protection under the law. Constitutional questions also have been raised regarding voting procedures and restrictions on filing a petition against the validity of an election.

In these cases, the Supreme Court confirmed that the power to determine election rules, except those rules specified in the Constitution, lies entirely within the discretion of the Diet. For instance, in a 1961 reapportionment case, ${ }^{12}$ the Supreme Court stated that because the power to decide election rules was delegated to the Diet, the apportionment of members of the Diet among election districts was a matter of legislative policymaking, except in cases of extreme disproportion. This reasoning has been applied in later cases on reapportionment, ${ }^{13}$ and the same justification was cited by the Supreme Court in a case involving a ban on canvassing. ${ }^{14}$

The 1950 Public Officials Election Act imposes various regulations on election campaigns, such as prohibiting bribery and unfair forms of influence. In addition to these prohibitions against corrupt practices that interfere with the free expression of a voter's will, many regulatory limitations and prohibitions have been imposed to ensure that election campaigns are conducted fairly and to avoid the exercise of undue influence over voters. ${ }^{15}$

One restriction on election campaigns, Article 138, section 1, of the 1950 Election Act provides that no one may conduct a door-to-door canvass with the intention of soliciting a vote for himself or another person or preventing the voter from voting for another person. This provision has been challenged many times as a violation of freedom of expression. The Supreme Court, however, has repeatedly ruled that it is not contrary to freedom of expression, despite some lower court rulings holding it unconstitutional. The Supreme Court denied the claim against a general ban on door-to-door canvassing because "whether or not canvassing shall be prohibited uniformly is a matter of legislative discretion (or policymaking powers) which shall be conducted from the point of preserving both freedom and fairness in elections, and then courts should defer to the judgment decided within legislative discretionary powers." 16

In Japan, voters go to the polls in their constituencies on election day and write the name of one of the candidates on a paper ballot and drop it into a

12. Koshiyama v. Tokyo Metropolitan Election Comm'n, 18 Minshū 270 (Sup. Ct., G.B., Feb. 5 , 1964).

13. Kurokawa v. Chiba Prefecture Election Comm'n, 30 Minshū 223 (Sup. Ct., G.B., Apr. 14, 1976).

14. Japan v. Yada, 35 Keishū 205 (Sup. Ct., 2d P.B., June 15, 1981).

15. The regulatory prohibitions and limitations included no campaigning before the specified date authorized by the election board, limits on the number of campaign pamphlets, restrictions on posters and poster displays, and prohibitions on canvassing at voter's houses. Public Officials Election Act (Koshoko Senkyō Hō), Law No. 100, 1950.

16. 35 Keishū 205. 
sealed box. They must act for themselves unless they are blind or physically handicapped, in which case they may vote by agent at the polls. They also may vote at a specified place other than an ordinary polling station before the election.

The 1950 Election Act provided another special arrangement for severely handicapped persons and pregnant women who found it difficult to go to the polling station by themselves; they were permitted to vote by mail. In 1952, however, the Diet abolished voting by mail on the ground that many illegal practices had occurred in the 1952 election of local government officials because of abuses of this special arrangement. In a 1985 case $^{17}$ denying a claim that attacked the abolition of voting by mail, the Supreme Court held that since the Constitution does not mandate the adoption of voting by mail, the power to make rules pertaining to the method of voting was within the discretionary powers of the Diet.

The Election Act also enables a voter or a defeated candidate to lodge a petition against the validity of an election. These petitions are reviewed by the court of appeals. If the court finds that illegal practices have been committed in the election, and that the irregularities were likely to have affected the result of the election, the court may hold the election void. ${ }^{18}$ In addition to this general provision, there is a special clause that authorizes the court to void the election result if an election agent, the general campaign manager of the candidate, or the person in charge of campaign spending is guilty of election offenses, even if the candidate himself did not commit such an offense. ${ }^{19}$ In 1959 , the election of one candidate to the local assembly was annulled because his election agent was guilty of committing an election offense. Both the lower court and the Supreme Court held this special provision constitutional because the rule was designed to have elections proceed fairly, based on the freely expressed will of voters, and without any disturbance. ${ }^{20}$

\section{F. A Case in Welfare Rights}

The Child Support Allowance Law, for children supported only by a mother, contains a section that prohibits a child support allowance if a mother receives another kind of public allowance of her own. A blind mother divorced from her husband applied for the child support allowance but was denied because she already received her own public allowance. In the 1982 Horiki case, ${ }^{21}$ in which this law was held constitutional, the Supreme Court

17. Sato v. Japan, 39 Minshū 1512 (Sup. Ct., 1st P.B., Nov. 21, 1985).

18. Public Officials Election Act, Law No. 100, 1950, art. 205. Even if the court finds that the irregularities were present at the election, it may determine that the result ought to stand since they were unlikely to have affected the result.

19. Id. arts. 251-52.

20. 16 Minshū 537 (Sup. Ct., G.B., Mar. 17, 1962).

21. Horiki v. Governor of Hyogo Prefecture, 36 Minshū 1235 (Sup. Ct., G.B., July 7, 1982); Beer, supra note 6, at 39. 
stated that arrangements for payment of various public allowances in the interest of fairness lay within legislative discretion.

\title{
G. Political Question Cases
}

Finally, I would like to comment on cases in which the Supreme Court applied the political question doctrine per se. In the 1959 Sunakawa case ${ }^{22}$ the Supreme Court said that

\begin{abstract}
the Security Treaty must be regarded as having a highly political nature which possesses an extremely important relation to the basis of the existence of our country as a sovereign nation. There are not a few points in which a legal decision as to the unconstitutionality of its content is simply the other side of the coin of the political or discretionary decision of the cabinet which concluded the treaty, or of the National Diet, which gave its consent to it. Consequently, a legal decision as to unconstitutionality has a character which, as a matter of principle, is not adaptable to review by a judicial function; accordingly, it falls outside the right of judicial review by the courts, unless there is clearly obvious unconstitutionality or invalidity. ${ }^{23}$
\end{abstract}

In a 1960 case concerning the power of the Cabinet to dissolve the House of Representatives, ${ }^{24}$ the Supreme Court held that decisions concerning a fundamental governmental action with a highly political character should not be made by the judiciary. Instead, the political branches of government, which are accountable to the people directly, or finally the people themselves should make these decisions, even if such decisions raise legal issues. The validity of the dissolution of the House of Representatives by the Cabinet was a political question. Although the government has repeatedly argued that the political question doctrine should apply in reapportionment cases, the Supreme Court has continually denied its claims. ${ }^{25}$ The doctrine has also been applied in some lower court cases concerning Article 9 of the Constitution, ${ }^{26}$ although the Sapporo District Court did not apply it in the Naganuma case, ${ }^{27}$ which dealt with the validity of the Self-Defense Forces.

Today, courts prefer to apply the legislative discretion doctrine rather than the political question doctrine when they intend to avoid constitutional adjudication or to refrain from interfering with decisions of the political branches of government. According to the courts' reasoning, under the legislative discretion test, courts refrain from interference with legislative judgment but retain the power to settle constitutional questions. If courts apply the political question doctrine, however, they may have to refrain completely from determining constitutional questions that arise in those

22. Sakata v. Japan (The Sunakawa Case), 13 Keishū 3225 (Sup. Ct., G.B., Dec. 16, 1959); J. MARI, supra note 4, at 298.

23. J. MAKI, supra note 4, at 305-06.

24. Tomabeji v. Japan, 14 Minshū 1206 (Sup. Ct., G.B., June 8, 1960).

25. See supra notes 12,13 . In these reapportionment cases, the Supreme Court applied the legislative discretion test, not the political question test.

26. Ministry of Agriculture \& Forestry v. Ito, 36 Minshū 1679 (Sup. Ct., lst P.B., Sept. 9, 1982) (aff'g 27 Gyōhan 1175 (Sapporo H. Ct., Aug. 5, 1976) and rev'g 712 Hanrei Jihō 24 (Sapporo Dist. Ct., Sept. 7, 1973)); Kobayashi, supra note 1, at 324.

27. 712 Hanrei Jihō 24. 
cases, and the political departments or the people themselves may have to make judgments on questions of constitutionality.

\section{III}

\section{An Analysis of Cases in Which Matters of Legislative Discretion Have Been Recognized}

\section{A. Rules Based upon Presumption}

The preceding brief survey of cases involving legislative discretion and political questions illustrates how the Supreme Court has upheld various legislative judgments as constitutionally reasonable actions within the discretionary powers delegated by the Constitution. It is important to question, however, what the Supreme Court has actually authorized through its deference to the legislative discretion or political question doctrines. What kind of constitutional rule in adjudication was established as a result of these decisions? In this section, I shall explain the common features of these cases. One common characteristic is that all the cases are concerned with generalized rules based on presumed facts.

1. The 1955 Case on Illegitimate Children. The innocent child in the 1955 case $^{28}$ was clearly a victim of the Civil Procedure Act and the Family Law. The procedural rule under which the plaintiff's case was dismissed is based on a legislative finding. The law presumes from the plaintiff's three-month absence without notice that the plaintiff no longer intends to continue his case. This presumption is not proven, and it is not true for all plaintiffs. If courts apply this rule absolutely to all parties, without providing them an opportunity to be heard, some plaintiffs will have their cases dismissed unreasonably, as in this case.

Second, the clause "within three years after the father's death" in the Family Law is also based on a presumed fact. There is a presumption under the provision that it is difficult to prove a father-child relationship three years after a father's death. It is also presumed that allowing an illegitimate child's claims to be raised more than three years after the father's death will obstruct certainty in the law of family relations. Neither of these presumptions is true in all cases. It is unreasonable to apply this clause mechanically to cases in which the father-child relationship is very clear.

2. The Patricide Case. The law on patricide has been justified as supporting moral values between children and parents. Patricide or matricide has been regarded as an offense that should be punished heavily because these offenses result from a child's violation of moral rules. A child has a moral obligation to respect parents and to repay them for their kindness. This moral obligation is quite different from the moral obligation of parents to children. Thus, the violation of a moral obligation by a child should be subject to heavier public

28. 9 Minshū 1122. 
blame than the violation of one by a parent. Imposing a heavier punishment for patricide than for other murders reflects the different quality of moral obligation that exists between parents and children than between nonfamily members.

The presumption here is that parents abide by high moral standards, not only in physically caring for the child, but also in teaching the high moral and legal standards of human society. If conflicts occur between a child and a parent resulting in the murder of a parent, the child should always be held responsible for the violation of a moral obligation.

The presumptions that support this moral rule are that parents always abide by high parental moral standards and, conversely, that a child who murders his parents is always bad. These presumptions are not a proven social fact. As the Supreme Court recognized in the 1973 patricide case, ${ }^{29}$ the violation of moral obligations by a child does not always deserve severe public blame and criminal punishment. The Court reached this conclusion from statistical data on punishment in patricide cases showing that, in most patricide cases, courts gave very lenient sentences to children who acted because of blameworthy conduct by their parents. Child abuse by parents preceding patricide or matricide was found to be a significant cause driving children to kill their parents. Thus, the behavior of parents is not always consistent with the presumed fact underlying the patricide law.

3. The 1985 Income Tax Case. In the salaried worker's income tax case, ${ }^{30}$ the rule on cost deductions differentiated salaried workers from nonsalaried workers. This rule presumes that the costs that are necessary for making profits are the same for all salaried workers, without exception. This fact is not proven. Clearly, the cost of producing taxable income differs depending on the type of work done by salaried workers.

4. Cases in Economic Regulation. When the "distance between bathhouses" regulation was held constitutional in the 1955 Fukuoka bathhouse case, ${ }^{31}$ the judicial deference toward the legislative findings with regard to the distance was widely criticized by many commentators ${ }^{32}$ because the facts that were asserted in the Diet, and found by the Court, were not true for all bathhouses. Free competition between businesses does not deteriorate the sanitary conditions of public bathhouses in all circumstances.

This defect in reasoning was recognized by the Supreme Court in the 1975 pharmacy case. ${ }^{33}$ Pharmacies were subjected to government licensing regulations, which included a distance requirement. The regulation on distance was justified by the same legislative reasoning as in the bathhouse

29. 27 Keishū 265.

30. 39 Minshū 247.

31. 9 Keishü 89.

32. As a recent comment on this case, see Yamashita, 100 Selected Constitutional Decisions, 1 Kenpō Hanrei Hyakusen 150 (N. Ashibe \& K. Takahashi eds. 1988).

33. Umehara v. Japan, 29 Minshū 572 (Sup. Ct., G.B., Apr. 30, 1975). 
case: Free competition invites unfavorable economic effects upon enterprises and results in the deterioration of medicine. This time the Supreme Court was not persuaded by this reasoning and held that the distance regulation was an unconstitutional restriction on the freedom of occupation guaranteed by Article 22 of the Constitution. The "free competition-unfavorable economic effect-deterioration of medicine" justification was based on a presumption that the court found to be an unreasonable judgment contrary to proven fact.

This judicial reasoning was not applied in the 1972 market case ${ }^{34}$ and the 1989 public bathhouse ${ }^{35}$ case because the Court found a reasonable legislative finding supporting the standard for distance regulations on these businesses. In the 1972 market case, an applicant for a new market in an Osaka neighborhood was not licensed by the Governor of Osaka although a competitor operating in this neighborhood welcomed the applicant. The Supreme Court recognized that regulating business activities is a matter of legislative discretion and that the distance regulation was reasonable because it protected a market operating with weak capital. The regulation prevented an old market's bankruptcy by placing limits on free competition. Reading the judicial factfinding in the context of modern marketing situations, the presumption in this legislative determination becomes clear. Although the same distance regulation was not imposed on a nearby supermarket, the cumulative effects of new markets could cause the bankruptcy of the old market.

5. The Cases on Election Rules. There are many presumptions among the legislative findings used to justify rules regulating elections. For example, the clause banning canvassing has been upheld by the Supreme Court on a number of occasions as a constitutionally permissible rule, because it is designed to prevent such election offenses as bribery, threats, and other unfair influences on voters. ${ }^{36}$ Thus, the legislature presumes that door-todoor canvassing is a cause of bribery and other unfair election practices, and is a disturbance in private life by unwelcomed visitors. However, these facts are not true for all voters. For some, canvassing is a welcome and convenient source of information on candidates, even if the same action is cumbersome for others.

When the legislature abolished the vote by mail for physically handicapped persons, and when it adopted a petition system for challenging an election's validity because of a campaign manager's election practice violations, it relied upon a number of presumptions. Voting by mail is not a cause of unfair election practices for all voters in all situations. This voting method is truly necessary for some disabled persons. Similarly, nullifying the election of a candidate when his or her general campaign manager is sentenced for an election practice offense presumes that a candidate knows every action of the

34. Marushin Sangyo Co., Ltd. v. Japan, 26 Keishū 586 (Sup. Ct., G.B., Dec. 22, 1972).

35. Kitagawa v. Japan, 43 Keishū 1 (Sup. Ct., 2d P.B., Jan. 20, 1989).

36. See Beer, supra note 6 , at 34 . 
campaign manager or that the manager is engaging in illegal acts at the direction of the candidate. Clearly, this is not always the case.

6. The Horiki Case. In the Horiki case, the Court based its opinion, in part, on presumed facts. In justifying a clause in the Child Support Allowance Act that disqualifies mothers who are paid their own public allowance from receiving a child support allowance, the Supreme Court stated that "it is not always true that double handicaps need double public allowances and triple handicaps need triple public allowances."37 Whether or not this is true depends on the particular circumstances that each party faces. Thus, the Court's holding based on presumed facts is insufficient justification for the constitutionality of this rule.

\section{B. Categorical Decisionmaking}

A second feature of the "legislative discretion" test is that it requires decisionmakers or judges to make a categorical decision. In categorical decisionmaking, the only task judges have is to find whether the predetermined factors that constitute the rule exist in a particular case. Thus, as a result of recognizing that some rules are matters of "legislative discretion," the Supreme Court rejects the need for individualized decisionmaking in each case.

The legislative discretion theory stresses certainty in the law and consistency in decisionmaking. ${ }^{38}$ To serve these values, certain clear rules need to be established. Although general rules applied uniformly often create inequitable results, the legislative discretion test allows these situations to exist in order to further the values of certainty and consistency in law.

For example, these considerations were predominant in cases concerning the rights of public employees in the $1970 \mathrm{~s},{ }^{39}$ in which the Supreme Court shifted from individualized decisionmaking to categorical decisionmaking. The National Public Employee Law and the Local Public Employee Law, examples of general rules made by the Diet, withheld the right to strike and banned political activities by public employees. These statutes absolutely prohibited public employees from striking. There were no exceptions, and persons who incite strikes were subject to severe criminal penalties.

Regarding the general ban on strikes for public employees, the Supreme Court in the 1960s adopted a quite different approach than in other fields. In cases involving the Tokyo Central Post Office, ${ }^{40}$ Tokyo Teachers Union, ${ }^{41}$ and

37. 36 Minshū at 1240 .

38. Capowski, The Appropriateness and Design of Categorical Decision-Making Systems, 48 ALB. L. REv. $951(1984)$.

39. Beer, supra note 6, at 23-26.

40. Toyama v. Japan (The Tokyo Central Post Office Case), 20 Keishū 901 (Sup. Ct., G.B., Oct. 26, 1966) (translated in H. Itoh \& L. Beer, The Constitutional Case Law of Japan 85 (1978)).

41. Hasegawa v. Japan, 23 Keishū 305 (Sup. Ct., G.B., Apr. 2, 1969). 
Sendai Judiciary Workers Union, ${ }^{42}$ the Supreme Court attempted to tailor individualized decisions by calling for "distinctions between types of public work, between legitimate labor dispute activities and political activities, between degrees of illegality and public inconvenience, and between mild sanctions and criminal penalties that are disproportionate for worker failure to perform contractual obligations."43 The Supreme Court stressed that penalties should differ depending on the types of public work and degrees of public inconvenience caused by labor strikes. However, in the 1973 All Japan Agriculture Forestry Workers Union case, ${ }^{44}$ the Supreme Court abandoned this approach and shifted to "a policy of comprehensive restriction of public worker rights based on a literal interpretation of statutes and disregard of the substantial diversity among types of public employees in Japan."45 Thus, in this field, the Supreme Court also has rejected individualized decisionmaking and returned to categorical decisionmaking. With this 1973 case, $^{46}$ moreover, the Supreme Court not only adopted a categorical decisionmaking approach in public employee cases but also explicitly rebuked the individualized approach because it was based on vague standards not mandated by statute and because it violated the due process clause of Article 31 of the Constitution.

The same categorical approach was taken by the Supreme Court in the 1974 Sarufutsu case, ${ }^{47}$ in which a legal restriction on the political activity of public employees was attacked as a violation of freedom of expression. The Supreme Court held the restrictive clause constitutional even though it applied to political activities that "[did] not impair performance of duty, [and were] engaged in away from official premises while off duty, and [were] performed by non-managerial service employees in a peaceful manner." 48

It is important to note the effects produced by the legislative discretion test. The test not only favors categorical decisionmaking over individualized decisionmaking, but it also allows categorical decisionmaking to be based on rules that are supported by presumed facts. This situation, as previously discussed, has often resulted in an imprecise judgment for each party.

An illegitimate child who could easily prove a relationship with his father was forced to remain in an illegitimate status because the "within three years" rule was supported by an irrebuttable presumption about the child-father relationship. In the patricide case, there was an inconsistency between the presumed facts and the reality of parental behavior. If a rule based on social myths about parents is applied to parents who do not conform to the

42. Japan v. Sakane (The Judiciary Workers Case), 23 Keishū 685 (Sup. Ct., G.B., Apr. 2, 1969) (translated in H. ITOH \& L. BEER, supra note 40, at 103).

43. Beer, supra note 6 , at 24-25.

44. Tsurozomo v. Japan, 27 Keishū 547 (Sup. Ct., G.B., Apr. 25, 1973); Beer, supra note 6, at 23.

45. Beer, supra note 6 , at 25.

46. 27 Keishū 547.

47. Japan v. Osawa (The Sarufutsu Case), 28 Keishū 393 (Sup. Ct., G.B., Nov. 6, 1974) (rev'g 514 Hanrei Jihō 20 (Asahikawa Dist. Ct., Mar. 23, 1968) and 560 Hanrei Jihō 30 (Sapporo H. Ct., June 24, 1969)); Beer, supra note 6 , at 26.

48. See Beer, supra note 6 , at 27. 
presumed fact, such parents are treated favorably only because they are "parents." Such an outcome results in unfair legal treatment and is contrary to the principle of individualized criminal punishment. There is no place for "guilt by association" 49 in the criminal law.

Using the patricide case as an example, the unfair results occur because the patricide law is based on presumed facts. The Diet based a criminal law on the concept of "parent and child," a group concept made in society, like race, sex, family origin, and social status. We are likely to use such concepts in making general rules. Under these general rules, the only task that decisionmakers have is to find whether predetermined factors are present. In a patricide case, if the decisionmaker finds that the victims are parents and the defendant is their child, the result will be reached mechanically, notwithstanding the legitimacy of the result. In this situation, the factors that are taken into account in making the decision are both predetermined and limited. There is no room for judges to consider other factors in order to reach a fair result.

In the 1973 patricide case, the Supreme Court held that the heavier penalty for killing a lineal ascendant than for ordinary murder was unconstitutional. However, the reason for the penalty's unconstitutional status should have been that the application of a rule supported by a presumed fact and resulting in individual injustice is not constitutionally permitted. The general rule on patricide should be abolished, and the general rules for murder should be applied to patricide cases. Article 199 of the criminal law concerning murder enables judges to take the actual situations of victims and suspects into account and fashion a fair judgment for individual defendants.

In the 1985 salaried workers' income tax case, , $^{\text {o }}$ the Supreme Court upheld as constitutional a general rule on the cost deduction system in income tax. Once this general rule was held constitutional, judges were not allowed to make individualized decisions on costs paid by a particular taxpayer in a salaried worker's case. Nor were they allowed to consider the various circumstances of salaried workers. The only thing that judges could do was to find out whether a given taxpayer was a salaried worker. On this basis, some salaried workers were forced to pay more income tax than nonsalaried workers on the same amount of income.

\section{IV}

\section{Limitation of Legislative Discretion}

A survey of cases in which the Supreme Court applied the legislative discretion test shows that there should be a constitutional limitation on discretionary judgments by the Diet. In considering to what extent legislative

49. Soifer, Guilt by Association, in Encyclopedia of the American Constitution 877 (L. Levy, K. Karst \& D. Mahoney eds. 1986).

50. 39 Minshū 247. 
discretion should be limited by the judiciary, it is necessary to comment on the relationship between parliamentary democracy and judicial review.

\section{A. Majority Rule and Abuse of Power}

The Constitution adopted the principle of government by laws that are adopted by the representatives of the people. Under this system, the people govern themselves through their representatives; it is the pattern of selfgovernment adopted in Japan. Since the governing power exercised by the Diet is derived from the people, the laws that are made by the Diet control not only the executive and the judiciary but also the people themselves. The Diet, as the supreme organ of state power, possesses enormous powers, including lawmaking, controlling finance and the activities of the executive, impeaching judges, and taking the initiative in the constitutional amendment process. The authority of the Diet extends to almost all matters pertaining to government-from national security to keeping and promoting the order, morals, health, safety, and general welfare of society. The Diet also may exercise broad discretionary powers on any question faced in society and has power to regulate by law any aspect of daily life. The emperor, the Cabinet, administrative agencies, the judiciary, and local public entities must perform their functions within the boundaries established by law. The Diet has, in truth, large powers; it is, indeed, the "supreme organ of state power." ${ }^{51}$ In this sense, the supremacy of the Diet is recognized by the Constitution.

The system of government through the Diet is based on a very optimistic view of human nature. There is an assumption that government through the Diet is a government of "men who possess most wisdom to discern and most virtue to pursue, the common good of the society." 52 The Constitution defines Diet members as "representatives of all the people" 53 and "the servants of the whole community," 54 not as representatives or agents of constituencies or servants of any particular groups. Diet members are expected to possess exceptionally high moral standards, discernment, fairmindedness, and a sense of balance required for statesmen as the representatives of all the people. They are guardians of liberty and equality and promoters of the general welfare. Under a government consisting of such statesmen, the trust of the people will not be betrayed. Harmonious society, where all people can attain happiness, is not just a vision but a reality. In such a society, governmental power need not be restrained because abuse of power is not expected to occur under this government.

The Constitution reflects not only this idealistic image of government based on an optimistic view of human nature, but it also expresses a

51. 1947 Const. art. 41; Ludwikowski, Judicial Review in the Socialist Legal System: Current Development, 37 INT'L \& Comp. L. Q. 89 (1988).

52. Tarcov, Popular Sovereignty (in Democratic Political Theory), in Encyclopedia or the American Constitution, supra note 49, at 1426.

53. 1947 Const. art. 43.

54. Id. art. 15(2). 
pessimistic view of human nature by implying negative attitudes toward governmental actions produced through unreasonable, passionate, hysterical, undeliberative, and selfish deeds of human beings. The Constitution refers to "horrors of war through the action of government,"55 "tyranny and slavery, oppression and intolerance," 56 "fear and want,"57 "abuse of freedoms and rights," 58 "discrimination in political, economic or social relations," 59 and "the illegal act of any public officials." 60 This pessimistic view of human nature is derived from the historical facts that gave rise to the Bill of Rights, Chapter 3 in the Japanese Constitution. Each clause of Chapter 3 reflects inhuman deeds in the past, and the possibility of their recurrence in the future, unless the ideal government presumed in the Constitution is maintained by "the constant endeavour of the people." 61

If such formidable and inhuman actions occur, even under democratic government, it is because the majority group abuses the governing power entrusted to it by the whole people. Thus, the Constitution adopted such features as separation of powers, judicial review, and impeachment to prevent the tyranny of the majority. Judicial review, established by Article 81 of the Constitution, is based on this pessimistic view of human nature. The appropriate role of courts, especially the Supreme Court, is to prevent the conscious or unconscious abuse of power by the majority in the Diet. Theoretically, under the government created by the Constitution, violations of human rights caused by the abuse of majority rule will not occur because the abuse of power and the violation of human rights are contradictory to selfgovernment by the people, even though it is carried out through the people's representatives. Since self-government was established after "the age old struggle of men to be free," 62 the abuse of power is expected to be restrained by the majority of the people. In actuality, however, the majority of the people cannot always be trusted. This fact suggests that the people should not trust themselves, even under democratic government. Thus, an instrument is necessary to check the abuse of majority power-the abuse of power by ourselves. Such a pessimistic perspective leads us to expect an active judicial role in the governing process. The problem is, however, how shall the courts be active?

\section{B. Judicial Attitude Toward Arbitrariness}

The discretionary powers that the Diet possesses are constitutionally limited. Articles 13 and 14 of the Constitution mandate that a policy made by the Diet should be compatible with the fundamental rule that each person has

\footnotetext{
55. Id. preface.

56. $I d$.

57. Id.

58. Id. art. 12 .

59. Id. art. 14.

60. Id. art. 17.

61. Id. art. 12.

62. Id. art. 97.
} 
a "claim to equal respect as an individual."63 Thus, in order to satisfy this requirement, rules should enable judges to reach an equitable result. According to this standard, many general rules made by the Diet are constitutionally suspect. If the Diet makes a general rule that judges shall make only categorical decisions, the Diet has probably abused, either consciously or unconsciously, its discretionary power. In the 1985 salaried workers' income tax case, as a result of the rule that directed judges not to make individual judgments on costs, some salaried workers were subjected to inequitable results without having an opportunity to rebut the presumed fact underlying the rule. The Constitution does not permit the Diet to use its legislative power in such an arbitrary way. Such an exercise of power should be declared void as an abuse of legislative discretion. The Diet should enact laws that enable administrators and judges to render a precise and fair decision or judgment for an individual party.

During the past forty years, the Supreme Court has expressed at least three different approaches toward legal rules that force individuals to accept unfair legal treatment. The first approach was that if the Supreme Court found an arbitrary element in the rule, it declared the rule unconstitutional. In the 1975 pharmacy case, ${ }^{64}$ for example, the Supreme Court recognized that the Diet had authority to regulate economic activities by balancing the freedom of occupation with public welfare, considering such factors as the purpose, necessity, and contents of regulation, the freedom of occupation, and the degree of restrictions on freedom. The Court concluded that it should defer to legislative judgment and discretion only so far as was reasonable. Applying this standard, however, the Court found that the "distance between pharmacies" regulation was not reasonable because the justification set forth by the Diet of preventing the deterioration of medicine was not compatible with the common sense of the people who were accustomed to prescription drugs in society and who knew that defects occurred in the drugs' manufacture and storage. Since pharmacies are just retail shops, the deterioration of medicine has no reasonable relationship to the distance regulation.

The second judicial approach toward legislative discretionary power is that the courts try to mitigate disadvantageous effects caused by a general rule. This is done by individualized decisionmaking through the interpretation of rules. An example can be found in a 1980 case in which the Kyoto District Court again faced the issue of the status of an illegitimate child who sought to be legitimated. The plaintiff took his case to court more than three years after his father's death. However, this time the court did not dismiss the claim and delivered a decision for the plaintiff. The father-child relationship was recognized even though more than three years had passed since the father's death. The Supreme Court subsequently overruled the decision of the Osaka Court of Appeals, which had applied the 1955 Supreme Court case as a

63. R. Dworkin, Taking Rights Seriously 13 (1978).

64. 29 Minshū 572. 
precedent. In reversing the decision of the Osaka Court of Appeals, which had applied the "within three years" clause strictly to this case, the Supreme Court took the following unusual circumstances of the case into account in order to mitigate the effects that would have been produced by strict application of the clause. ${ }^{65}$

In 1975, the child's parents celebrated a wedding and signed their names on the official paper along with signatures of witnesses for registration. Unfortunately, they did not register their marriage at the local government's office immediately after the wedding ceremony. The following year, the plaintiff was born. The child's father, however, had left home without notice before the child's birth. Nobody knew where the baby's father was and whether he was alive when the baby was born. Since his mother had both the marriage and birth registered at the same time, the child was registered as a legitimate child. After these registrations were completed, it was learned that the baby's father had died three months prior to the baby's birth. As a result, the status of this child was changed legally from legitimate to illegitimate. When the child raised his claim to be recognized as the legitimate child of the deceased man, more than three years had passed from the date of his father's death. Legally, his claim should not have been accepted by the courts because it had not satisfied the "within three years" requirement for such a claim.

In making a judgment about the three-year requirement, however, the Supreme Court held that, in this case, the beginning date for the three years' limitation should be the date when the plaintiff was notified of his father's death, not the date of his father's death. The Court found that to ask the plaintiff to raise a claim within three years after his father's death was to ask the impossible because the child had enjoyed the status of a legitimate child until he was notified of his father's death. Such a fair result was reached by an individualized judgment, based on the equity power of the court. Thus, the Court restricted legislative discretion indirectly, by preventing a general rule made by legislative discretion from reaching an unreasonable and unfair effect.

The third approach taken by the Supreme Court toward legislative discretion is that the Court will hold rules constitutional even if it finds some degree of arbitrariness in them. In the 1955 case involving an illegitimate child, all courts denied an individualized decision although they felt that the general rule inflicted an unfair effect on an innocent child.

The same approach was taken in the 1974 and 1981 cases banning, respectively, certain kinds of political activity and voter canvassing. In these cases the Supreme Court justified some degree of unconstitutionality in the rules by a kind of cost-benefit analysis. In justifying a political activity ban for public employees the Supreme Court said:

Although freedom of expression is limited by this ban, interests which are gained by it (it preserves the political neutrality of public employees and the peoples' trust in

65. Horiuchi v. Japan, 36 Minshū 432 (Sup. Ct., 2d P.B., Mar. 19, 1982). 
unbiased administrative action) are far more important than interests lost by this ban.

Thus, this ban is not disproportionate. ${ }^{66}$

The same justification was applied in the 1981 canvassing ban case to authorize some degree of arbitrariness in the rule. ${ }^{67}$

By balancing interests, the Supreme Court has tolerated some degree of arbitrary judgment for individual persons on the pretext of implementing a more valuable purpose. This kind of reasoning has aroused a sense of unfairness in defeated parties because the Supreme Court has not only abandoned its role of remedying unfair treatment, but it also has not required the Diet to act promptly and to base its actions on the principle of equity. Thus, an inequitable treatment or imprecise judgment for a particular party has been left without a remedy through any governmental organ.

\section{$\mathrm{V}$ \\ CONCLUSION}

Most of the cases in which the Supreme Court has applied the legislative discretion doctrine illustrate the third type of judicial approach. The first and the second mitigating approaches are exceptions in this field. In this sense, the legislative discretion doctrine plays almost the same role as the political question doctrine in constitutional litigation. The Supreme Court is extremely reluctant to interfere with matters of legislative discretion except when legislative judgment is grossly unreasonable. This judicial attitude has been criticized as a symptom of nonactivism by the Japanese Supreme Court. ${ }^{68}$ Many commentators urge the Supreme Court to take a more active role in implementing constitutional values such as "peace," "freedom," "equality," and "wholesome and cultured living." These comments are very understandable in the context of the contemporary government process in Japan.

However, under the constitutional government in which the Diet has been delegated many important governing powers by the people, another allocation of responsibility between the Diet and the Supreme Court is possible. Perhaps the Diet should exercise its equity power more actively. This action should be done even if the Supreme Court refrains from declaring rules unconstitutional. Under the Japanese Constitution, the equity power is given to the Diet, not to the Court. Because the Diet consists of representatives of all the people and servants of the whole community, it is entrusted with the equity power. The Supreme Court can exercise the equity power based on delegation, in various forms, from the Diet. The equity power is usually delegated by means of an exception clause to a general law.

The Diet has exercised its equitable power in this form to remedy the defects that a general law might bring about. A good example can be found in

66. 28 Keishū 393.

67. 35 Keishū 205.

68. For a recent work discussing the nonactivism of the Japanese Supreme Court, see $\mathbf{H}$ Tomatsu, Judicial Review (1989). 
the election law. Under the law governing voting in 1950 , voters had to go to the polling stations by themselves on polling day and write a candidate's name on the ballot paper by themselves. If this was the only rule concerning the method of voting and was applied uniformly to all voters without taking a voter's physical condition into account, many handicapped voters would be forced to give up a chance to participate in the political process. But these unreasonable and unfair results were avoided by such exception clauses as absentee voting, voting by mail, and voting by proxy. These exception clauses are products of the legislature exercising its equity power. The Diet should make similar rules to implement the fundamental constitutional requirement of "equal respect as individuals," even if courts do not require the Diet to do so. The Diet should be the agent of equity, the supreme guardian of values that the Constitution protects.

In the field of legislative discretion, the courts should awaken the Diet, as "the highest organ of state power," to its duties. In order to play this role, the Supreme Court should indicate arbitrary aspects of laws either by obiter dicta or by advisory opinions and urge the Diet to enact more equitable laws, even if it refrains from holding a law unconstitutional, as it did in the 1983 reapportionment case. ${ }^{69}$ The active authorization of rules by the Supreme Court based on cost-benefit analysis should be avoided, since it not only has a negative effect on the legal action of the Diet (as happened after the Horiki decision), ${ }^{70}$ but also because it undermines the image of the Court as a public forum for fairness and justice. Whenever the Supreme Court finds arbitrariness and injustice in laws, it should advise the Diet to take prompt action to rectify them.

When the Supreme Court applies the legislative discretion or political question doctrines, it should not be the end of the constitutional process but a reaffirmation of it. Here, too, the Diet should realize its accountability to all the people and to the whole community.

69. Tokyo Metropolitan Election Comm'n v. Koshiyama, 37 Minshū 1243 (Sup. Ct., G.B., Nov. 7,1983 ).

70. The Diet abolished a clause alleged to be unconstitutional in the Horiki case. It reestablished the clause after the Supreme Court upheld its constitutionality. 
